\title{
Relendo a pintura contemporânea de Senise e Lambrecht: um caso escolar
}

\author{
MARIA REGINA JOHANN \\ GICELDA DE LUCCA FLORES
}

Resumo

Este texto apresenta um recorte de uma pesquisa monográfica e o desenvolvimento do tema em uma prática de Estágio Supervisionado no Ensino Médio. Nele relacionamos as questões centrais acerca da pintura contemporânea tendo como referência as obras de Daniel Senise e Karin Lambrecht e relatamos como esse tema foi abordado em um projeto de estágio no qual buscamos proporcionar a ampliação do conhecimento sobre arte contemporânea a partir das pinturas dos artistas citados, proporcionando aos alunos uma experiência teórico-prática com a pintura contemporânea.

Palavras-Chave:

Pintura contemporânea, apropriação, arte/educação 


\title{
Rereading the contemporary painting of Senise and Lambrecht: a school case
}

\author{
MARIA REGINA JOHANN \\ GICELDA DE LUCCA FLORES
}

\section{Abstract}

This paper presents part of a monographic research and a theme development in a supervised trainee practice in High school. It presents the key topics about the contemporary painting, using as reference works of Daniel Senise and Karin Lambrecht. The paper also describes the approach used in the trainee project in which we tried to provide the

Key words: Contemporary paint, appropriation, art/education students the oportunity to improve their knowledge about the contemporary art through a theorical and practical experience on the work of the previously mentioned artists. 


\section{A pintura contemporânea no contexto da educação escolar: experienciando impregnações, acasos e marcas}

"Foi interessante adquirir novos conhecimentos sobre conteúdos e obras que antes nós desconhecíamos. Foi importante também para conhecer novos artistas com visões diferentes sobre a arte". (Aluna Kaline Damiai)

\section{Situando a proposta desenvolvida}

Inicialmente, destacamos que este texto não tem a pretensão de dizer "como" ensinar sobre arte, se não, de socializar uma proposta desenvolvida, com a clareza de suas finitudes, pois entendemos que a proposição não significa, necessariamente, prescrição. E, fizemos isso, justamente para romper com o sentimento que habita o imaginário de muitos professores, que é o medo de dizer como fez, assumindo as potencialidades e contradições de suas propostas. Desse modo, não temos a pretensão de substituir os sujeitos em seus contextos, pois cada um toma para si aquilo que lhe interessa e reinventa.

Ensinar sobre arte contemporânea com ênfase para pintura contemporânea foi o desafio da proposta construída para a $1^{\mathrm{a}}$ Serie do Ensino Médio do Colégio Jesus Maria José, de Palmeira das Missões, no interior do Rio Grande do Sul. A intenção inicial era a de proporcionar aos estudantes do ensino médio uma experiência com a arte contemporânea, pois na grande maioria das escolas, essa serie é a última etapa escolar na qual os estudantes têm o componente curricular arte. Daí, a ênfase para o contemporâneo. Tínhamos como principal objetivo ampliar as referências conceituais, 
mas também, proporcionar uma experiência artística que desinstalasse e subvertesse padrões e concepções de arte, para a maioria, acadêmicos.

Definido o tema, "pintura contemporânea", o desafio era eleger obras que dessem conta de ampliar o repertório artístico dos estudantes e que, principalmente, causassem um estranhamento sobre o universo da arte. E foi no trabalho de Daniel Senise ${ }^{1}$ e Karin Lambrecht ${ }^{2}$ que encontramos os elementos artísticos e os conceitos básicos sobre o que desejávamos ensinar: diferentes e inusitados materiais e suportes, também, ideias como apropriação e referências ao cotidiano.

A partir disso, elaboramos o projeto para vinte horas de aula e buscamos organizar os materiais didáticos para a sua realização. As aulas foram conduzidas através da abordagem teórico-prática dos conteúdos conceituais, procedimentais e atitudinais de modo dialógico, proporcionando uma compreensão crítica dos assuntos tratados. Através das vivências teórico-práticas dos conteúdos e, inspirados nas obras de Karin Lambrecht e Daniel Senise, os alunos puderam apreciar imagens e documentários, discutir e experimentar diferentes materiais, procedimentos e meios. Foram instigados a relacionar sobre o que estavam estudando em relação ao que experimentavam plasticamente. Também foi proporcionado aos alunos viagens de estudo para Porto Alegre, onde visitaram a Fundação Iberê Camargo, o Museu Arte do Rio Grande do Sul (MARGS), a Usina do Gasômetro e a Casa de Cultura Mário Quintana.

Nas aulas, apresentamos o assunto de modo diverso, proporcionando a apreciação das reproduções das obras dos artistas mencionados e, algumas vezes, mostrando reproduções de obras da tradição para que, ao compararem, pudessem observar as rupturas artísticas e estéticas ${ }^{3}$, assim como, problematizamos sobre as transformações relativas às concepções de arte, materialidades, meios e procedimentos.

Também apreciamos os DVDs ${ }^{4}$ sobre os trabalhos realizados pelos artistas, provocando o aluno a observar a particularidade de cada proposta e o modo como apresentam suas pesquisas. Nesse momento, a ênfase foi para o diálogo em torno do assunto, por considerar fundamental que os alunos reflexionem sobre o que perceberam. Diante disso, foram desafiados a escolher uma obra como mote para realizar uma experiência semelhante a dos artistas, ou simplesmente experimentar materiais para verificar a plasticidade da técnica, percebendo os elementos formais e cromáticos 
em diferentes suportes. Desejávamos que experienciassem o ato criador, sem a pretensão de condicionar a uma única ideia ou obra, mas que pudessem se surpreender, assim como, ser surpreendido pela matéria.

\section{Razões da proposta}

A arte contemporânea mexe com nossas referências tradicionais, rompe com paradigmas, categorias e padrões estéticos. Relaciona objetos do cotidiano com materiais tradicionais e inter-relaciona linguagens, meios e procedimentos. A produção artística se expandiu e se modificou, fazendo com que, muitas vezes, a própria obra necessite da participação do público para existir plenamente. Com essa afirmação, não estamos desmerecendo a arte do passado e, nem afirmando que a contemplação por ela proposta não proporcionava interação, reflexão e o conhecimento, pois, como nos lembram as professoras Gisa Picosque e Miriam Celeste Martins (2007, p. 352) "[...] a sensibilidade não está exclusivamente naquele que olha, escuta ou toca a obra. A própria obra é 'pregnante' de sensibilidade que exalam na forma suas forças sensíveis".

Assim, consideramos relevante tratar de arte contemporânea na educação básica, pois abordar esse tema amplia a compreensão sobre o lugar da arte no mundo humano e também possibilita a compreensão que a arte é social e histórica. Desse modo, se a sociedade se modifica em relação à ciência, às tecnologias e padrões sociais, também se modifica em relação à arte e aos padrões culturais.

Apresentar aos estudantes as principais transformações artísticas ocorridas ao longo da história humana, possibilitando que problematizem sobre os padrões estéticos, as ideias e os materiais, auxilia também que compreendam melhor o que o artista faz no contexto atual.

A arte tem um lugar significativo no contexto social e, se entendermos que deve ser importante na escola o que tem importância fora de seus muros, seria de se esperar que ela tivesse um lugar de destaque na instituição escolar. No entanto, mesmo tendo entre seus objetivos a transmissão de "cultura e conhecimento", sabemos que, apesar de avanços e conquistas nas últimas décadas, a arte ainda ocupa um lugar bem menos importante do que poderia no cotidiano escolar.

Sabemos que ensinar sobre arte vai além da realização de técnicas e representação de narrativas; num contexto atual, 
exige do professor uma postura propositiva e mediadora, atenta às questões da arte e também da cultura visual, contemplando na medida do possível, as mestiçagens decorrentes da arte contemporânea. Para Imanoel Aguirre (2009, p. 157) “[...] parece irremediável é a urgência de renovar as ideias básicas e os imaginários que constituem o funcionamento da maioria das nossas atuais propostas em educação artística [...]", sob pena de não darmos sentido àquilo que realizamos. Também os referenciais nacionais para a área, os PCNs Arte, indicam que devemos ampliar as narrativas de ensinar sobre artes visuais, destacando as questões sobre a arte contemporânea.

A educação em Artes Visuais requer trabalho continuamente informado sobre os conteúdos e experiências relacionados aos materiais, as técnicas e as formas visuais de diversos momentos da história, inclusive contemporâneos. Para tanto, a escola deve colaborar para que os alunos passem por um conjunto amplo de experiências de aprender e criar, articulando percepção, sensibilidade, conhecimento e produção artística pessoal e grupal. (PCN, 2000, p. 61)

Ampliar as possibilidades de aprendizagem em ambiente dialógico faz com que o aluno se sinta autorizado a manifestar sua visão sobre o que está estudando e experimentando, mas também, permite a problematização sobre aquilo que é dado como conhecimento ou verdade histórica e, muitas vezes, absoluto. Nesse diálogo professor e aluno confrontam ideias, testemunham saberes e significam aprendizagens.

Segundo Ana Mae Barbosa, "a arte leva os indivíduos a estabelecer um comportamento mental que os levam a comparar coisas, a passar do estado das ideias para o estado da comunicação, a formular conceitos e a descobrir como se comunicam esses conceitos. Todo esse processo faz com que o aluno seja capaz de ler e analisar o mundo em que vive, e dar respostas mais inventivas"s.

Como um dos propósitos era causar estranhamento, principalmente em relação a materiais e procedimentos, encontramos nas obras dos artistas Daniel Senise e Karin Lambrecht um universo amplo de possibilidades, compostas de pinturas nada convencionais para o universo da arte, principalmente em relação à arte da tradição ${ }^{6}$. As rupturas da arte contemporânea em relação à arte moderna têm suas origens em Marcel Duchamp ${ }^{7}$, na medida em que apresenta um ob- 
jeto do cotidiano como obra de arte e, faz dessa atitude, uma reflexão sobre quem diz o que é arte e quais os critérios que a valoram. Essa proposição tomou corpo e, nos meados dos anos sessenta, a arte amplia seus caminhos e passa também a incorporar com mais ênfase objetos do cotidiano, assim como, as tecnologias, por exemplo. De acordo com Cattani (2007, p. 25), "no momento contemporâneo constata-se que a arte é campo de experimentação no qual todos os cruzamentos entre passado e presente, manualidade e tecnologia, materiais, suportes e formas diversos se tornam possíveis". Assim, na arte contemporânea existem diferentes estratégias criativas, como indica Cattani (2007, p. 29), que geram "problematizações internas ao conceito de mestiçagem nas produções artísticas atuais e em exemplos da modernidade, que constituem as poiéticas dos artistas ou as poéticas da obras que lhes dão consistência”. Essa amplitude gera uma infinidade de termos e categorias para a arte contemporânea, questões pertinentes ao ensino de artes visuais.

\section{Daniel Senise e as impregnações como pintura}

Conhecido como um dos artistas pertencentes ao grupo Geração 8o Daniel Senise é sem dúvida um dos nomes marcantes do cenário artístico atual. Sua poética é fruto de uma arte feita com coerência e intensidade. Podemos dizer que Senise reinventou as formas de pintar, retirando do chão, aparentemente vazio, os 'pigmentos' e suas formas. A pintura emerge deste espaço impregnado em que ele recorta e rearranja em impressões, decompondo e recompondo os feixes impressos na matéria-prima. Seu trabalho sugere que pensemos em conceitos como: impregnação, apropriação e hibridismo.

Tendo como horizonte a obra e o atelier de Senise, o desafio para os alunos era de proporcionar experiências semelhantes e, a partir disso, passamos a olhar para o espaço escolar buscando "encontrar" este lugar onde o tempo tivesse deixado suas marcas. Encontramos o galpãozinho da escola, um lugar onde se guardam os objetos inúteis. Ali, percebemos um ambiente semelhante aos lugares em que Senise buscava elementos para apreender os vestígios, pois havia azulejos e cadeiras velhas, objetos de ferro já enferrujados, arames, ferramentas estragadas e muita poeira.

Foi neste lugar que os estudantes realizaram as primeiras experiências plásticas desta proposta. Receberam reta- 

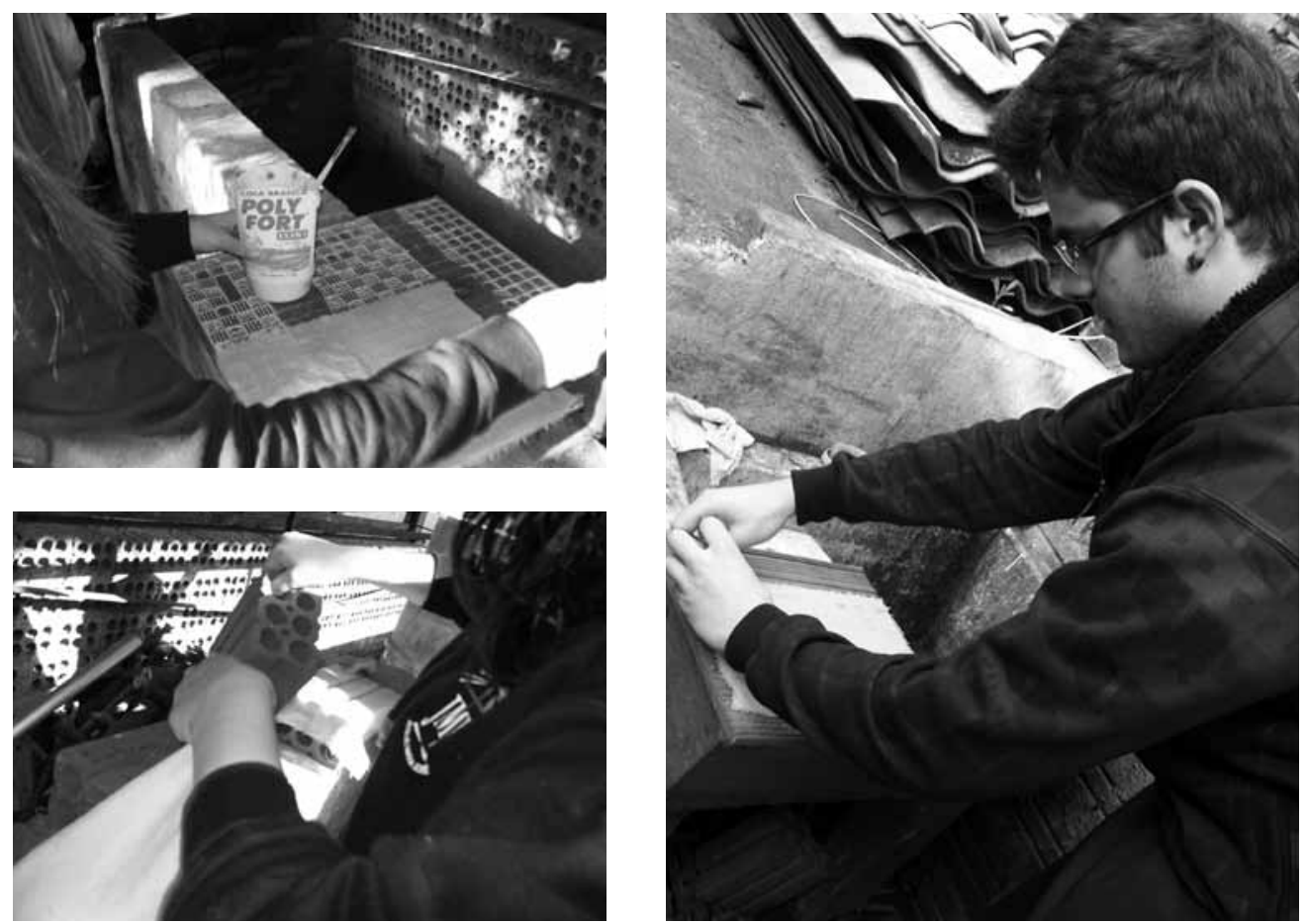

Figura 1 Imagens de alguns alunos pesquisando impressões com impregnação

lhos de cretone, cola diluída em água e tinta para tecido de seda. Com este material realizaram impregnações e também frottage ${ }^{8}$, colocando o tecido umedecido sobre os objetos, conforme ilustram as imagens.

Na medida em que vivenciavam uma pintura semelhante à de Senise, os estudantes passaram a olhar o trabalho do artista de modo diferente, entendendo melhor o conceito de pintura contemporânea e visualizando como ela foi reinventada ao longo da história. Relacionaram o que fizeram como a pesquisa do artista, percebendo a força expressiva e capacidade de Senise em reinventar e, por vezes, romper com técnicas e materiais artísticos convencionais.

Essa relação entre a apreciação de imagens e a experiência artística do aluno forneceu elementos para a professora entender melhor o lugar da análise da obra na aula e, como isso, ajudou os alunos a perceberem que o artista é um pesquisador, e que também relaciona sua produção com a tradição. Compreenderam que Senise conhece sobre arte e busca no passado elementos para fomentar seu trabalho, como ilustra Ivo Mesquita (1994), quando afirma que as pinturas de Senise estabeleceram 
uma relação direta com a história da arte, com o universo das imagens e os seus modos de construção e percepção.

Testemunhas do compromisso do artista com a pintura como linguagem, o conjunto delas demonstra uma articulada orquestração de significantes - o próprio meio expressivo, a superfície plana, apropriação, representação, percepção, cultura de massas e o seu imaginário pessoal - em trabalhos que, longe de ser pura expressão pictórica, inauguram o retorno à pintura como diferença conceitual e positiva da modernidade que orientou as gerações precedentes. (MESQUITA, 1994, p. 13)
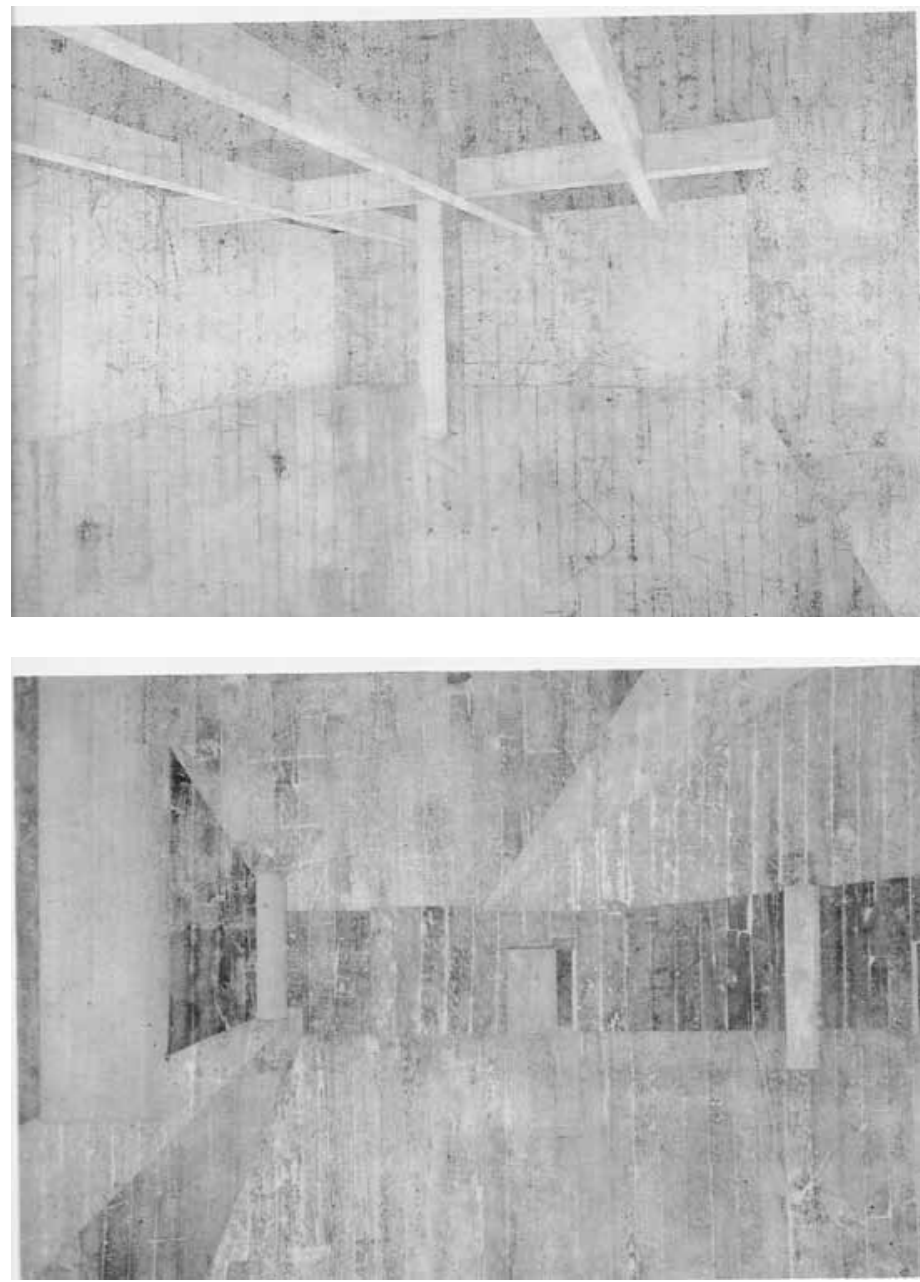

Figura 2

Sem título 2002

acrílica sobre algodão sobre madeira - $200 \times 300 \mathrm{~cm}$ Coleção Galeria Britto Cimino, São Paulo
Figura 3

Galician Center for Contemporary Art, Acrílica em colagem sobre madeira,

$200 \times 300 \mathrm{~cm}, 2000$

Retirado do site danielsenise.com em 30/01/11 
zeram, passa a compreender que os mesmos têm propósitos, que estão em busca de "respostas" para suas "perguntas" e, que a responderem, inauguram o ser.

Ao compararem as obras dos artistas com suas produções, os alunos verificaram elementos comuns: acasos, surpresas, frustrações, ludicidade, tempo.

A partir destas comparações, foi possível discutir com a turma o modo como Senise e Lambrecht provocam rupturas significativas na arte, pois ao capturar marcas, manchas e formas, reinventam a pintura. Aqui, a ênfase foi para a ideia de pintura que o artista apresenta e sua capacidade de ampliar os meios e os procedimentos de pintar. Tanto Senise, quanto Lambrecht trabalham com a apropriação e isso, de certo modo, autorizou os alunos a buscar diferentes modos de impregnar cores, formas e texturas.

Mesquita (1994) observa que Senise foi se dando conta do esgotamento ou das limitações das estratégias "neo" e como que para encerrar o que se pode chamar de seu período de formação "lança-se, em seguida, num embate direto com a tela e com a criação de imagens, que, embora às vezes preexistentes e referenciais, são indissociáveis dos processos de fatura investidos em sua formação”. Ele destaca ainda que, "[...] as cores passam a ser mais intensas e variadas e as formas sobre as telas, mais pictóricas do que gráficas, recolocando-se a questão figura e fundo, ausente na produção anterior [...]" (MESQUITA, 1994, p. 13).

Conhecer e problematizar sobre o trabalho dos artistas relacionando às experiências vivenciadas na escola contribuiu para que os estudantes pensassem sobre o fazer artístico como uma ação intelectual e não somente prática. Por isso, ao pesquisarem impregnações em superfícies empoeiradas, os alunos exploraram outros materiais, como a impregnação da ferrugem sobre o tecido, por exemplo, observando a ação do tempo como elemento constitutivo da pintura. Umedeceram o tecido com álcool, espalharam sal grosso e colocaram o objeto de ferro e arame sobre este tecido e tiveram que esperar alguns dias para verificar o que aconteceria. Nesse caso, questões como tempo, imprevisibilidade, acidente e ação (também da ferrugem sobre o tecido) foram discutidas como elementos plásticos e estéticos.

Os procedimentos de impregnação e frotagge não são novos nas aulas de arte, mas nessa proposta assumiram outra conotação. Essas técnicas foram tratadas como pintura 

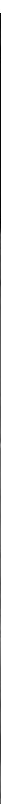

Figura 5 e, assim, foi possibilitado aos estudantes que continuassem

Ilustração de pinturas/ impregnações com tecido umedecido em álcool e sal sobre objetos enferrujados trabalhando nelas, interferindo ou agregando outros materiais. A professora se empenhou em relacionar a prática dos estudantes com a pesquisa dos artistas, desse modo, contextualizou o fazer artístico e possibilitou que ampliassem o significado do que estavam fazendo. Tomamos como referência o próprio conceito de pintura de Senise e, ao capturar formas e texturas das superfícies de objetos do cotidiano, os estudantes ampliaram sua visão sobre pintura. Desse modo, foi possível relacionar essa experiência com a vivenciada pelo artista, pois Senise conta como chegou neste processo.

[...] Ah, isso foi um acidente. Eu tinha sido convidado a participar de uma exposição coletiva em Paris, uma exposição brasileira no Museu de Arte Moderna de Paris. Paralelamente, havia uma exposição em um outro espaço, dessas que não têm verba. Você ganhava a passagem e levava o trabalho debaixo do braço. Eu pensei em fazer telas muito grandes e comprei um rolo de tecido. Preparei as telas no chão, que era o chão impregnado do meu ateliê, e na hora em que tirei a tela, o lado que estava contra o chão parecia uma tela minha, até porque, era o material que eu retirava das minhas pinturas que estava naquele chão9. 
Ao observar o acaso na sua tela e assumir isso como pintura, Senise passa a trabalhar nessa perspectiva e investigar também novos suportes e maneira de compor e criar formas. Com a mudança das telas de lona para cretone, tecido mais permeável, e com a adoção de procedimentos técnicos como o frottage e marouflage ${ }^{10}$, a pintura de Senise ganha especificidade e adensamento. Desse modo, Mesquita (1994, p. 14), destaca que "tais procedimentos resultam em uma pintura desenvolvida em muitas etapas, dando ao artista uma elasticidade espacial, o que lhe permite fazer coexistir simultaneamente, na mesma superfície, áreas de opacidade e de vertiginosa profundidade".

As obras de Senise passam essa ideia de que tudo pode ser registrado, nem que apenas um traço permaneça, pois esse já poderá relatar parte da história, que algumas vezes fica gravado somente na memória do artista. $\mathrm{O}$ procedimento que desenvolveu para mostrar esses vestígios é assim descrito por Arthur Omar (2002, p. 22-24):

Exerce-se pressão sobre essa tela para que a mesma adquira intimidade absoluta com o chão que será o seu destino. Quando retirada, a tela traz consigo a poeira invisível do chão, as marcas, sulcos, restos, imperfeições, desgastes, derrapagens, frutos do uso, do percurso, do tráfego humano, e todos os seus acasos, que largaram ali micro-índices materiais de um tempo que já é pura memória. [...] Pintura abstrata, sem intervenção de mão humana. Pintura 'aplicada', no sentido literal do termo.

Os recortes formam quase uma fotografia decalcada desse ambiente em que o fundo e os recortes praticamente se fundem, eles podem ser as paredes de um museu ou do próprio quarto do artista, ou seja, ele vai "buscar" a pintura, percebendo onde ela pode estar.

\section{Karim Lambrecht e a pintura como registro e memória}

Muitas das questões já referidas a Senise também valem para Karin Lambrecht. Com ela a pintura ganha novos contornos, pois pintar pode ser muito mais do que preencher um suporte com tintas e figurações. Pintar, para Lambrecht é, também, acontecimento. Ao contemplar o conjunto de sua obra, é pos- 
sível relacionar a pintura com um modo particular de fazê-la. O espaço, o dia, os materiais, as pessoas e o acontecimento da pintura. Sobre isso Agnaldo Farias (2002, p. 14) comenta:

O projeto artístico de Karin Lambrecht avança ignorando a arte. As cores de suas telas não são extraídas de tubos de tintas industrializados, mas de pigmentos naturais, dos grãos da terra ao sangue derramado do abate dos animais. Muitas vezes são realizadas ao ar livre, com a artista tomando uma vassoura como pincel, para, depois, deixá-las ao relento, sujeitas a ação do sol, do vento e da chuva, que lhes vai alterando ainda mais a aparência, como se fossem co-autores da obra, que não compartilham com a artista o rumo que está sendo dado. Como o tecido e a estrutura de madeira, as cores que vão sobre as telas pertencem ao mundo, não são elementos idealizados; dele trazem o peso, a textura, o cheiro.

Farias (2002), destaca inclusive que a artista se acostumou com o silêncio, enquanto sua geração, a Geração 8o, trouxe para si as luzes, ela rumou solitária em seu ateliê em Porto Alegre. Lá foi fabricando seus meios de expressão, usando suportes diferenciados, fugindo dos cânones da pintura, trazendo para a sua pintura outros elementos, como tecidos rasgados e queimados, sucatas industriais, sobras de utensílios, chapas e ripas de madeira, entre outros. A própria artista comenta sobre seu trabalho, confirmando a tese do crítico: "Trago para dentro da pintura o próprio rio - a água e a terra - o barro [...]; vou tentar uma unidade entre a gestualidade, o material e uma forma central que pode se expandir até as bordas da área ${ }^{12 "}$.

Os alunos estudaram a série Registros de Sangue, em que a artista realiza a pintura com sangue e as vísceras de carneiro. Refletiram sobre o sacrifício/abate do mesmo, e problematizaram sobre a experiência em determinado contexto, como ocorre nessa Série. Nesse momento, foi fundamental o conhecimento da professora sobre a pesquisa da artista, pois, desse modo, pôde apresentar aos alunos a visão de Lambrecht sobre o abate do animal, assim como, o drama diante dessa prática. Com isso, os alunos desconstruíram a ideia de que a artista estava compactuando com a violência ou praticando rituais do mal, como muitos, a princípio, pensaram.

Os trabalhos que realizei até hoje recolhendo o sangue do abate de carneiros (ou ovelhas), especificamente em lugares 


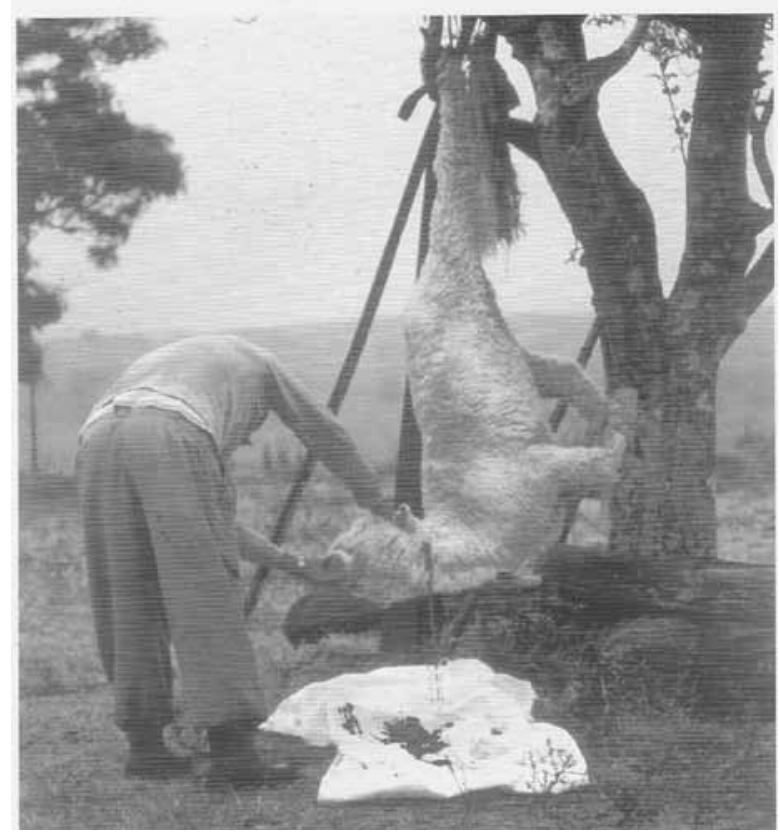

escolhidos a priori e sempre muito isolados, geralmente lugares muito simples onde, às vezes nem havia luz elétrica, nunca foram fáceis, porque exigem que haja confiança dos peões em mim. Quando eles realizam o abate, precisam estar à vontade e aceitar a minha presença. Eu nunca interferi no método do oficio deles. O meu trabalho tem que estar nos 'conformes éticos' aos olhos do abatedor para que eu possa estar presente junto a eles. É um momento horrível. Sei de antemão o que será visto, a morte de um carneiro, os sofrimentos do animal sendo abatido de um só golpe de faca. Creio que o trabalho que apresento contém a memória destes fatos, porém é uma memória invisível ao olhar, mas esta lá. [...] Eu considero a mancha de sangue como uma sombra da matéria, algo como uma tensão contínua da existência orgânica gerando constantemente um conflito entre corpo e espírito. [... $]^{13}$

Nas pinturas realizadas com sangue a artista foi mais a maestra do que a executora. Respeitando o significado daquele ato para quem o realizaria, Karin Lambrecht se limitou a disponibilizar os tecidos no entorno do animal abatido, assim como a sugerir que cada um dos participantes daquele ritual, pintassem com as vísceras do animal. Aqui, temos mais um
Figura 7

Imagem extraída do catálogo de exposições "Karin Lambrecht" MARGS, 2002 
elemento significativo para refletirmos que é a ideia da pintura "feita a muitas mãos", ou seja, a pintura como um acontecimento coletivo em que a própria autoria é compartilhada.

Já mencionamos que, na série de Registros de Sangue, Lambrecht apresenta novas formas de fazer pintura e, sobre elas, Farias (2002) comenta que o trabalho foi realizado a várias mãos, é compartilhado, e começou com o contato dela com os homens que se ocupam do abate de ovelhas numa região próxima a Bagé, interior do estado do Rio Grande do Sul. Esses homens não são sacerdotes nem açougueiros, mas trabalhadores que desempenham tarefas do cotidiano da estância. $\mathrm{O}$ abate dos animais acontece com uma série de cuidados que aproxima de um ritual. A artista teve que provar a seriedade de seu trabalho e, como um acontecimento ela assistiu, junto com seus convidados, o animal ser suspenso e sangrado até o fim, a maneira do rito judaico.

Lambrecht utiliza materiais diferenciados em suas obras, desde os pigmentos até os suportes que são utilizados. Os pigmentos são extraídos da natureza, da terra, da chuva, do sol, do sangue e das pegadas de animais. São materiais que também se transformam, sofrem alterações pela sua própria natureza e, com isso, vão alterando o seu trabalho, como se estivessem ajudando-a. Muitas vezes, os suportes da pintura estabelecem relações com o passado, com a história familiar e com a espiritualidade. Como é o caso das roupas, das toalhas e dos objetos particulares que a artista, por vezes, utiliza ${ }^{14}$.

Quando os alunos conheceram as pinturas de Lambrecht, o estranhamento em relação à arte aumentou, pois a materialidade do sangue foi um elemento perturbador. Vejamos o modo como o aluno Victor explicitou sua compreensão das pinturas estudadas e, observemos que, mesmo impactado, ele reconhece a força expressiva da obra: "Eu achei o aspecto denso e questionador que exigem uma interpretação mais profunda". O aspecto marcante foi à percepção de que as pinturas, mesmo realizadas com materiais como sangue ou, cola e poeira, eram consistentes e convincentes. Para ele, as obras de Lambrecht e Senise provocaram um pensamento perturbador. O que Victor percebeu é que a arte tem conteúdo, ou seja, é filosófica, pois coloca questões para pensar, além dos aspectos plásticos para fruir. As obras estudadas e a experiência artística vivenciada desvelaram, entre outras coisas, a "densidade" da obra e o caráter filosófico da arte.

Se, para Senise, o pigmento pode estar nos resíduos do chão, para Lambrecht, pode estar nas vísceras de um carnei- 

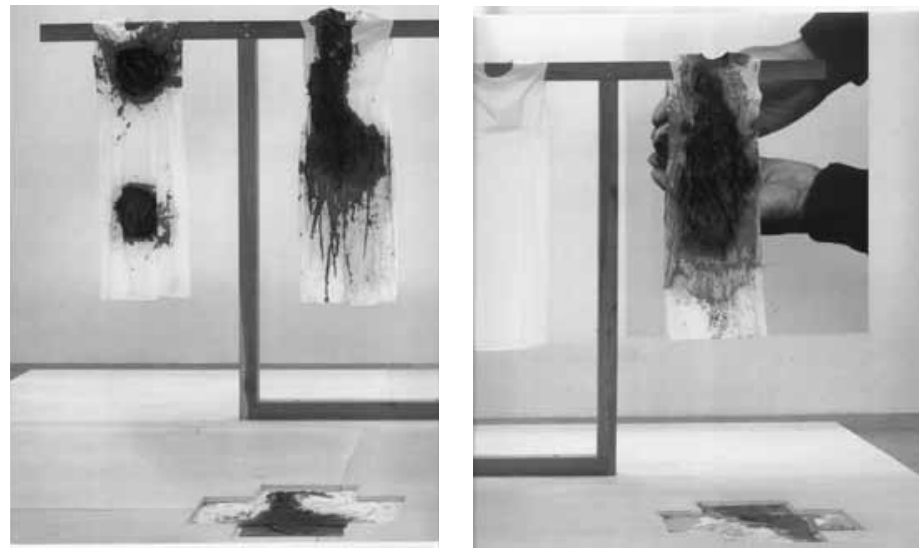

Figura 8

Imagem extraída do catálogo de exposições "Karin Lambrecht" MARGS, 2002

ro. Mostrar isso aos alunos foi um desafio para a professora, pois algumas das pinturas da artista não são agradáveis de ver (especialmente para um público de adolescentes), por outro lado, elas tocam justamente por esta plasticidade que evidencia o sangue, por exemplo.

Para Cattani ${ }^{15}$ "as obras de Karin pegam pela emoção, mas possuem uma enorme carga de reflexão por trás [...]. Estética não é forçosamente o belo, mas aquilo que provoca uma reação e, este trabalho nos confronta com questões essenciais do ser humano, que são a vida e a morte". Isso foi um dos enfoques dados pela professora no momento de analisar as pinturas da série com sangue.

Ao apresentar o modo como a artista encara a sua produção, a professora explicou alguns elementos importantes que desconstruíram um viés de violência e insensibilidade por parte da artista. Lambrecht sempre se preocupou em não atrapalhar e não interferir no trabalho dos peões durante o abate, pois ela está lá nesse momento para registrar a morte do animal, não de forma explícita, mas de forma memorial, num 'confronto' entre corpo e espírito.

[...] trata-se de jogos especulares, nos quais nos vemos no corpo figurado ou sugerido; corpos que se transformam, que se desdobram em nossos corpos. Trata-se ainda de ambiguidades de sentidos, no vai e vem entre o Eu e o outro, que estabelecem múltiplas e variáveis relações. Quando o corpo do animal entra em cena, substituindo o humano, levantam-se questionamentos sobre o sujeito: até que ponto nos assemelhamos a esses corpos, que queremos acreditar irracionais, até que ponto nos diferenciamos? Outras são as questões pro- 
vocadas pelo corpo materializado pelo sangue e pelas vestes, ou pelo sangue nas vestes em obras de arte: corpo conteúdo/ continente, presente/ausente, vivo/morto. Faz-se presente uma tensão permanente: entre vida e morte, entre animal e humano. Essa tensão não é, no entanto, negação da possibilidade da convivência. (CATTANI, in Araújo, 2008, p. 30)

Para Cattani (2002, p. 22), "a artista jamais se interessou pela representação, mas segundo suas palavras, 'mais pela matéria da pintura', a matéria, isto é, o suporte, os materiais (inclusive os diversos materiais agregados às pinturas ao sabor de seus impulsos)". Conforme a autora, Lambrecht não interferiu durante o "derramamento" do sangue do animal, , apenas foi organizando os tecidos sob o pescoço do animal para o sangue jorrasse sobre os mesmos. Aqui, fica evidente uma das características da arte contemporânea, que é a relação entre a ideia e a execução da obra. Nem sempre o trabalho, ou seja, a feitura da obra será realizada integralmente pelas mãos do artista. Muitas vezes, ele será o 'mago inspirador', o sujeito da ideia, da autoria.

Figura 9 Imagens extraídas do livro "Eu e Você" (2001)
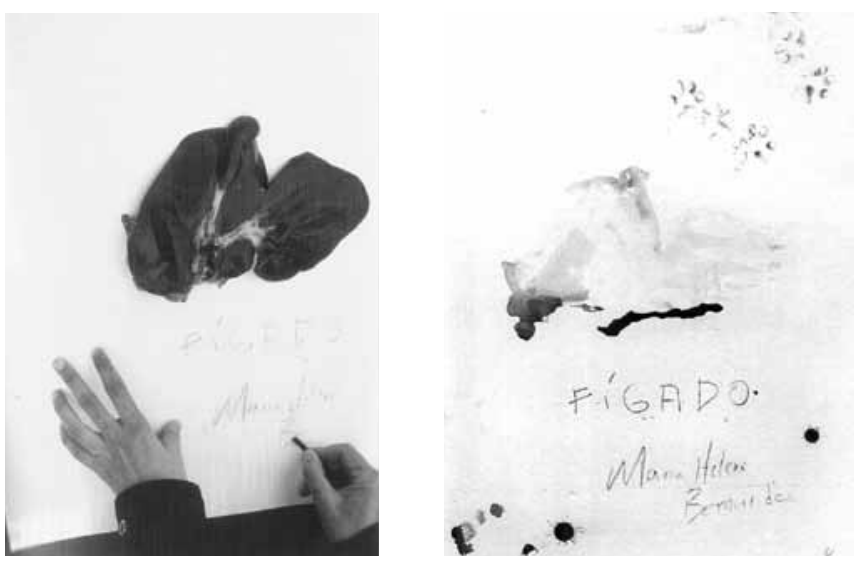

Para Miguel Chaia (2002, p. 37), Karin realiza uma obra que tem como referência a vida e a arte, pois ela:

[...] não quer representar a natureza, mas sim estabelecer um constante diálogo com ela, através da observação da sua lógica e requisição da sua materialidade. Recolhe temas que nascem do meio natural e do ambiente transformado pelo homem; utiliza como recursos de visualidade vestígios deixados pela vegetação, animais e minerais. Aquilo que a natureza 
descarta Karin recolhe, seleciona e utiliza para transmutar a natureza em signos plásticos, em recursos de linguagem, para criar uma nova realidade na esfera da arte.

Desse modo, é evidente que a artista busca ampliar a relação entre a materialidade e a natureza, se apropriando de imagens, formas, cores e, inclusive, rastros de animais.

Chaia (2002) observa ainda, que Lambrecht produz uma obra viva, que procura estimular a percepção e o sentimento, procurando não deixar que se esqueçam da natureza e dos seres vivos. Através da arte, ela faz ligações entre o indivíduo e sua relação com o outro. "Cada obra de Karin propicia um momento particular de reflexão, que trás a consciência de que o Eu e o Nós podem se encontrar na arte" (CHAIA, 2002, p. 37). Nesse momento, o expectador pode se igualar ao animal, ou a árvore, ou a terra. Por mais que Lambrecht concentre seus pensamentos na arte, ela não possui uma visão antropocêntrica, "faz de sua vida uma experiência estética e, de sua obra uma proposição ética" (CHAIA, 2002, p. 37). A artista é daqueles exemplos de quem dá significado a ideia da "estética da existência", remetendo a relação do eu com o mundo, assim como, uma obra de arte.

Karin Lambrecht e Daniel Senise nos convocam a olhar para o entorno e ver aquilo que muitas vezes está velado, pois levados pela lógica do cotidiano vamos transformando valores, modificando comportamentos e nos afastando cada vez mais da natureza, assim como, esquecendo da nossa historicidade. No bojo da pós-modernidade, os artistas nos lembram das coisas vitais para a condição humana, como por exemplo, o pertencimento, a história e a inter-relação entre o humano e a natureza.

Provocados pela ideia de que podemos inventar maneiras de pintar, os estudantes foram estimulados a pensar diferentes pigmentos, e instigados a experimentarem uma pintura semelhante a que Lambrecht realizou. Assim, usaram terra, café, beterraba, anil e também sangue de galinha. Após o preparo dos 'pigmentos', pintaram os pedaços de cretone para, depois, realizarem a composição a partir dos pedaços de tecidos que receberam.

Nessa experiência, os alunos demonstraram curiosidade em pintar com materiais não convencionais, expressando relutância somente em relação ao pigmento sangue. Sobre isso, a professora observa que as dificuldades foram mais complexas, pois eles sentiam "nojo" só em pensar que iriam trabalhar 
com sangue ${ }^{16}$. Somente um grupo se disponibilizou em trabalhar com o material, os demais optaram por outros pigmentos.

Na medida em que os alunos foram refletindo sobre as pesquisas dos artistas e relacionando com seus trabalhos, foram compreendendo que as coisas não estão dadas, mas que é uma questão de construção. O que torna uma ideia válida é o modo como a potencializamos. Em nosso entendimento, refazer (na medida do possível) uma experiência semelhante a do artista potencializa o debate sobre o fazer artístico como algo que tem um propósito e, que não é tão simples como, muitas vezes, parece. Ela fornece ao professor e seus alunos elementos para reflexão sobre a arte do artista e a arte escolar ${ }^{17}$. Com isso podemos tematizar qual é a diferença entre a especificidade da arte e a especificidade do ensino da arte. Acreditamos que, com esse debate, o aluno aceita melhor as finitudes de suas realizações artísticas e, compreenda que, o que está em questão, não é o padrão da execução de uma técnica, mas sim, a ideia, a experiência, a aprendizagem e o sentido que assume para cada um.
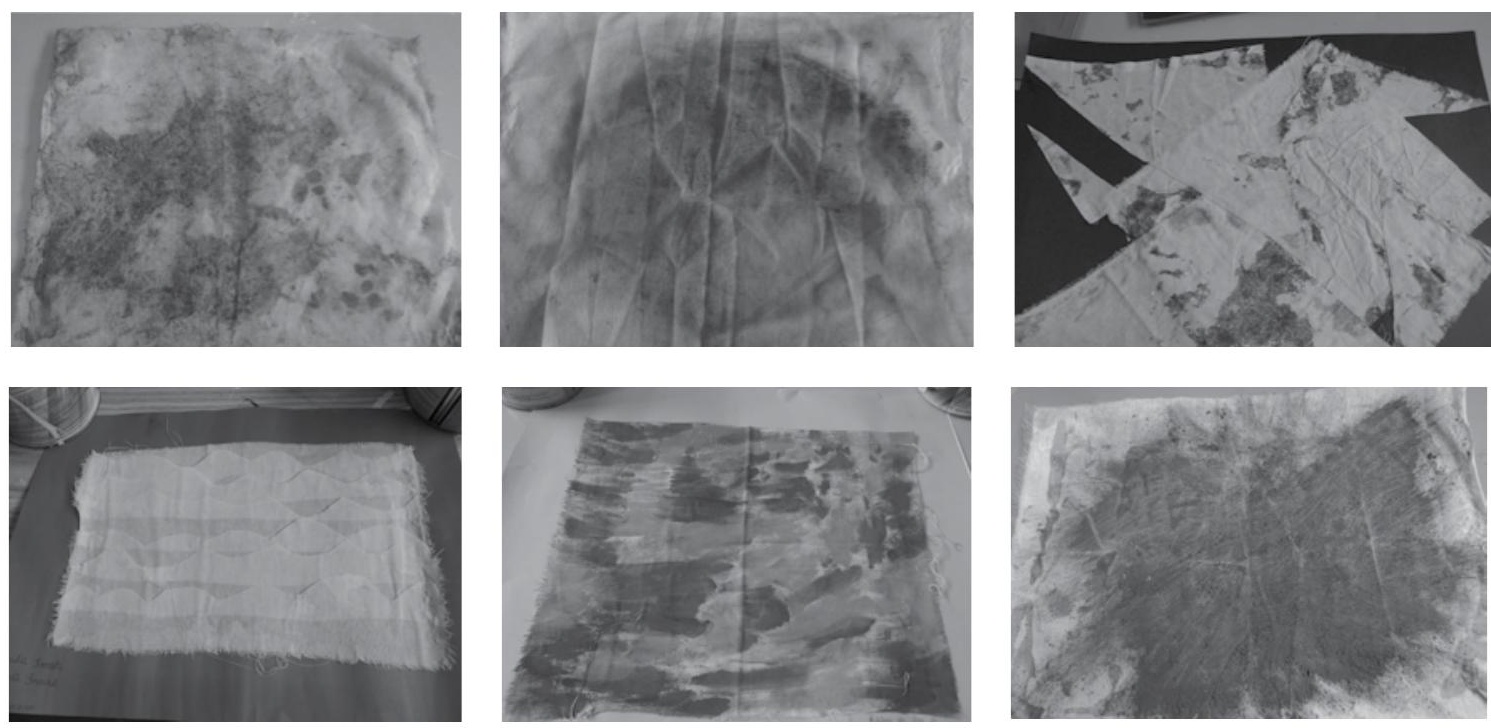

Figura 10 Trabalhos dos alunos com tingimento de anilina, café e beterraba
Pensamos que cabe ao professor proporcionar experiências com diferentes meios e modos de expressão artística, contemplando aspectos da arte da tradição até o contemporâneo. Seria muito salutar, se os alunos construíssem, ao longo da sua vida escolar, um conhecimento das principais transformações ocorridas ao longo da história da arte, mas 
também pudessem vivenciar de forma mais alargada experiências com a arte contemporânea. O depoimento da aluna Bárbara, por exemplo, nos faz acreditar nisso: "achei muito interessante por conhecer novos tipos de pintura, que não sabia que existiam, por aprender novas culturas e me sentir mais preparada". Observamos que conhecer sobre arte indicou caminhos e possibilidades para Bárbara, porque apreciando diferentes obras e experimentando procedimentos semelhantes, ela alargou sua bagagem técnica e conceitual. A aula de arte possibilitou para a aluna aquilo que talvez fora dos espaços escolares, ela não conhecesse. Seu depoimento ilustra uma das funções da escola que é proporcionar o contato com a diversidade de manifestações artísticas e culturais e ampliar as possibilidades de escolhas, na medida em que o aluno expande seu repertório e constrói critérios para analisar e, também criar.

Compreendemos que a arte deve ser vista como campo de conhecimento, produto da cultura e parte da história com códigos e gramática própria. Se entendermos que a arte é uma linguagem, então o aluno tem o direito de conhecê-la e, por ela saber se expressar. Como linguagem universal, contribui na formação do sujeito para o desenvolvimento de seu autoconhecimento, do conhecimento do outro e das culturas de diferentes tempos e espaços. Para Ana Mae [...] "O fazer é muito importante para despertar a capacidade perceptiva para as nuances da construção artística" [... ${ }^{18}$ e, como fica evidente no depoimento da aluna Vitória que achou " interessante e ao mesmo tempo diferente o modo como eles se expressam através de suas obras". Abre-se uma compreensão das possibilidades de produção artística, a experiência com a arte contemporânea ajudou no entendimento que na arte, a regra é "não ter regra".

$\mathrm{O}$ arte/educador David Thistlewood (2005, p. 114) argumenta sobre o sentido da experiência com a arte contemporânea e sugere aspectos sobre como pode ser ensinada nas escolas, questões pertinentes ao foco deste trabalho:

Acho pertinente sugerir que os estudantes têm direito ao acesso à arte 'contemporânea' através de suas práticas. $\mathrm{O}$ perigo está, neste caso, na simples imitação. [...] Mas a simples imitação das técnicas - mais exatamente a carência de técnica e a subsequente perda da 'naturalidade' (artiessness) - de algumas das expressões contemporâneas é considerada improdu- 
tiva pelo critério educativo normal. Deste modo, o que estou sugerindo é um meio de ensinar arte 'contemporânea' produtivamente, baseando-se nos conceitos de construção (de uma experiência prática de arte 'contemporânea', de des-construção do anterior (para acomodar critérios pessoais) e da constante re-construção dos conceitos estéticos resultantes.

É possível observar nos argumentos do autor a relevância de o professor assumir que sobre arte se ensina e, nesse caso, a arte contemporânea requer, por parte dele, um conhecimento conceitual e, também, metodológico. A pergunta que fica, a partir das afirmações de Thistlewood, vai em direção do modo como propomos a aprendizagem aos nossos alunos, ou seja, se conseguimos proporcionar uma experiência teórico-prática capaz de significar e gerar a compreensão daquilo que estão fazendo. Para o aluno Vitor, essa experiência contribui para que percebesse que o artista inventa procedimentos e experimenta materiais surpreendentes, ou, pouco convencionais para a arte: "Gostei que os autores faziam coisas inimagináveis pelas pessoas, coisas que ninguém pensaria”. Talvez o que fica para Vitor seja a compreensão de que o limite da criação está na ideia do artista. Além das tintas... O sangue, a terra, a poeira... A memória.

Neste sentido, Thistlewood (2005, p. 125) argumenta que:

[...] arte 'contemporânea' - e até sua extrema variante, a 'vanguarda' - pode ser ensinada. Nós podemos fazer categóricas distinções entre 'moderno' e "contemporâneo". O "moderno" pode ser ensinado por meios teóricos, mas nós também podemos recordar alguns de seus aspectos na 'contemporaneidade' para a assimilação prática. Conceitos 'contemporâneos', e outros conceitos que são re-citados para a 'contemporaneidade' podem ser absorvidos através da des-construção - uma importante tarefa face as grandes complexidades de informação no domínio público.

Quando o professor conhece sobre o assunto que se propõe ensinar e, consegue construir situações didáticas eficazes para atingir seus objetivos, temos como resultado um ensino mais coerente com os propósitos escolares. O desafio proposto neste estágio possibilitou a aluna Isadora viver uma experiência singular, aquilo que Jorge Larrosa ${ }^{19}$ chama de "experiência que nos atravessa". Disse ela: 
Realizar uma pintura com sangue na aula de educação artística foi uma experiência realmente muito diferente, que eu nem sequer imaginava que teríamos a oportunidade de realizá-la. Eu achei muito legal poder fazer isso. Para mim, foi fácil, pois não tenho 'problemas' com sangue como muitas pessoas têm, não tenho nojo, então foi normal, como trabalhar com uma tinta qualquer, a única coisa que me incomodou foi o odor que ficou depois de pintar, e o sangue com qual realizei o trabalho era de galinha, e ele estava um pouco coagulado, então tive que misturá-lo com água e mexer para depois poder pintar. (ISADORA, 2011)

Para Isadora, a experiência foi além da plasticidade da pintura, mexeu com vários sentidos possibilitando vivenciar uma pintura que, além de "ser muito legal", nem sequer imaginava. Para ela, a arte desinstalou a ordem, pois foi uma experiência fora do convencional. Seu depoimento nos estimula a ousar em nossas proposições, pois nos surpreendemos e, também, os surpreendemos.

A experiência com diferentes materialidades e concepções artísticas pode empoderar o aluno a criar diferentes respostas plásticas para sua produção escolar. Abaixo, imagens de pinturas a partir da experimentação com diferentes tintas e pigmentos, tendo como conceito central a ideia de impregnação. Nesse caso, decalcaram tecidos com cola sobre superfícies empoeiradas, enferrujadas e também produziram a partir da relação entre tinta, álcool e sal.
Figura 11

Trabalhos dos alunos com álcool, ferrugem, sal e tinta. Tecidos umedecidos e dispostos sobre ferramentas como enxada, arames, folhas de zinco para impregnação da ferrugem. Cola para superfícies empoeiradas.
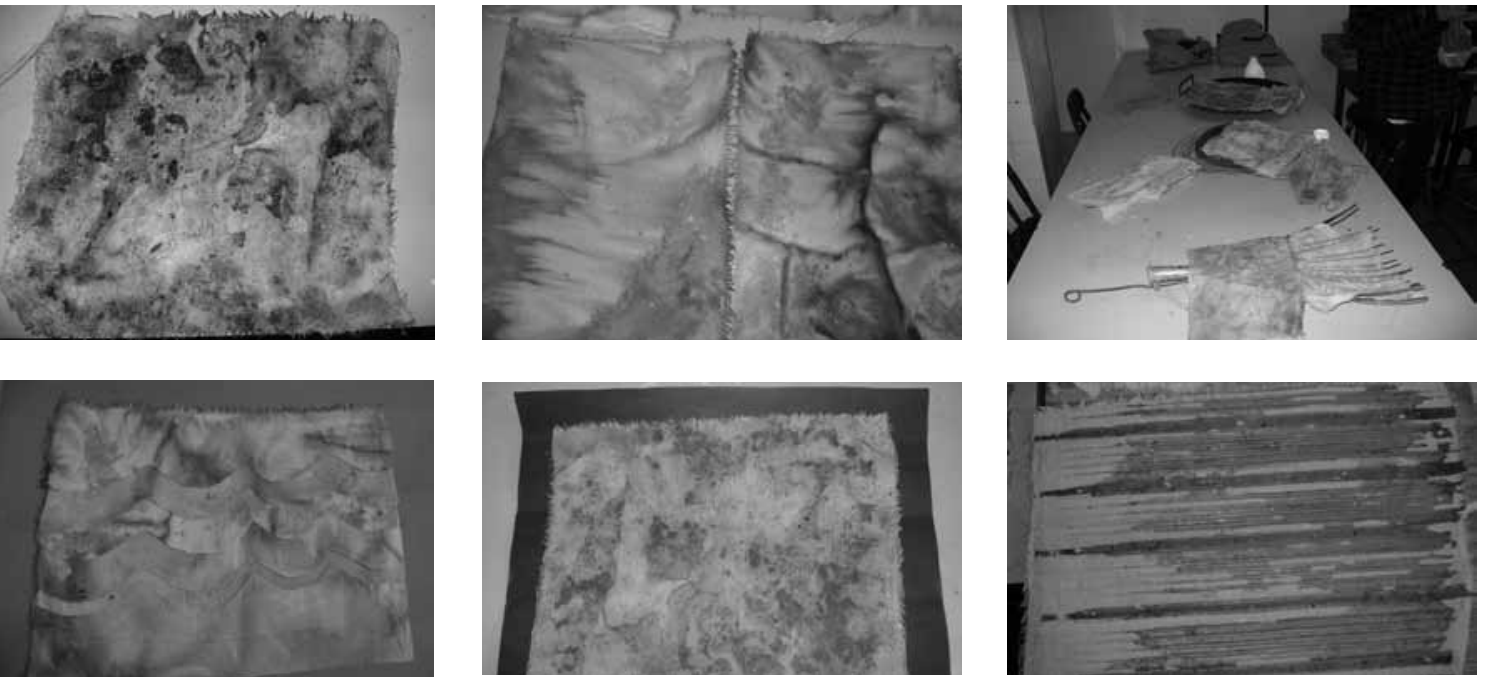
A partir desse trabalho, constatamos o que a professora Ana Mae afirma quando se refere à arte e seu ensino. Para ela, “[...] Por meio da Arte é possível desenvolver a percepção e a imaginação, apreender a realidade do meio ambiente, desenvolver a capacidade crítica, permitindo ao indivíduo analisar a realidade percebida e desenvolver a criatividade de maneira a mudar a realidade que foi analisada" (BARBOSA, 2003, p. 18).

\section{A experiência artística além da escola}

Mencionamos que também era objetivo dessa proposta possibilitar aos alunos uma experiência cultural diferenciada; entendíamos que o contato com exposições em diferentes espaços daria conta de mostrar o lugar da arte no contexto social. Com isso, pretendíamos que eles relacionassem a arte, o artista, os espaços de cultura com o lugar da arte enquanto componente curricular e, principalmente, estar na presença da obra, que entendemos ser uma experiência insubstituível. Assim, os alunos realizaram uma viagem de estudos a algumas instituições artísticas de Porto Alegre.

No Museu de Arte do Rio Grande do Sul (MARGS), apreciamos a exposição "Guignard"; na Casa de Cultura Mário Quintana, a Exposição Coletiva de Artistas Vidreiros e na Usina do Gasômetro, observamos algumas obras semelhantes àquelas em que trabalhamos com ferrugem e, vale destacar que, nesse momento, houve o reconhecimento e a identificação do grupo, a partir daquilo que estudaram nas aulas.

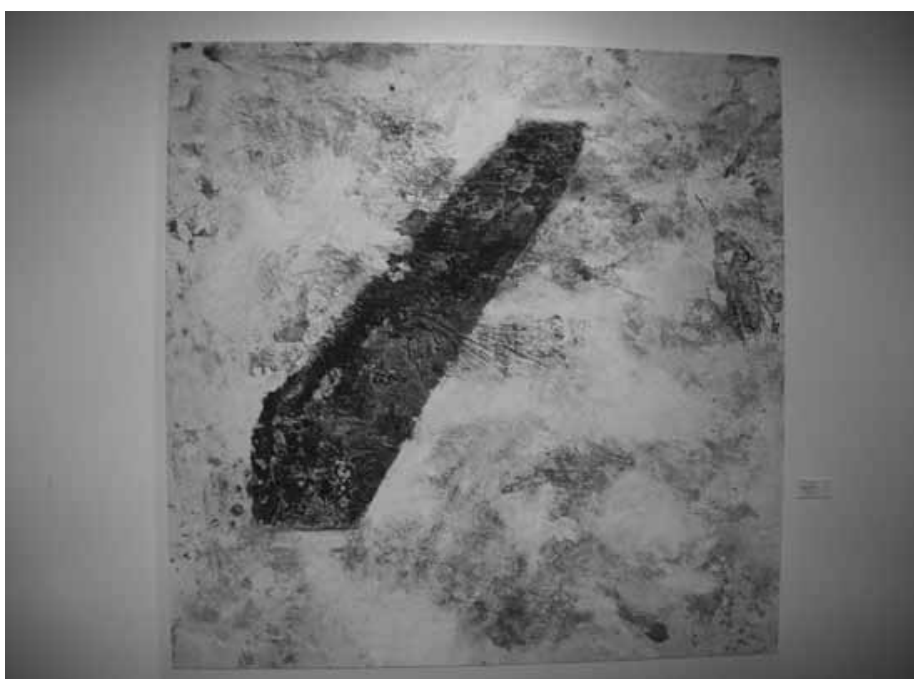



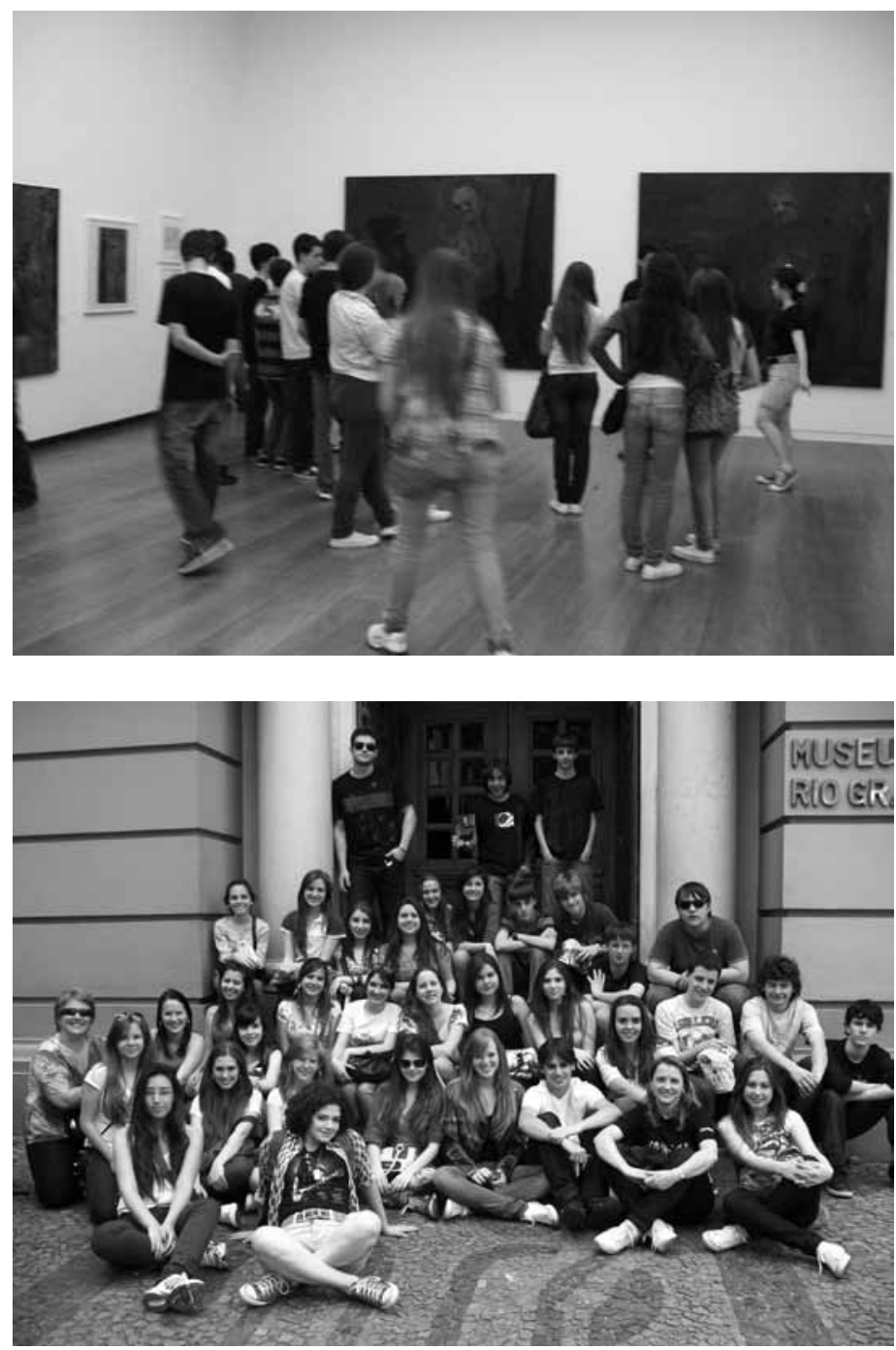

Por último, fomos ao Museu Iberê Camargo que apresentava a exposição "Desenhar no Espaço" de artistas abstratos do Brasil e da Venezuela. Além dessa mostra, também havia a exposição de Iberê, "Os Meandros da Memória”. Apreciamos suas pinturas e constatamos que, além dos materiais e procedimentos utilizados pelos artistas estudados, as técnicas de pintura tradicional continuam sendo utilizadas, embora com propósitos diferenciados em relação à tradição. Essa viagem serviu também como encerramento do estágio, possibilitou alargar a experiência com a arte e a cultura, relacionaram o que estuda-
Figura 13

Visita ao Museu Iberê Camargo e MARGS - Museu de Arte do Rio Grande do Sul 
ram ao que viram nos museus; compreendendo que a arte fornece subsídios para a arte escolar e que ela se legitima na escola quando faz sentido na vida escolar de professores e alunos.

Olhar/ver a obra nos lugares instituídos também contribui para legitimar o trabalho da professora, isso fica como testemunho do lugar que a arte se apresenta. A expectativa era de que voltariam com suas "mochilas" recheadas de arte e cultura e, assim, teriam mais bagagens para suas futuras criações escolares.

Conforme Martins (2004, p. 238):

Olhar a arte, especialmente quando se tem a tarefa desafiadora de ensinar e aprender, é também perceber a alfândega interpretante - o ponto de passagem entre o dentro e o fora de crianças, jovens, adultos que conosco caminham no campo da arte, da cultura, da ciência. No cruzamento desses dois mundos, cada um desses aprendizes carrega suas bagagens, lotadas de repertórios pessoais, recolhidos dentro de determinado tempo, cultura, valores, de ideias e produções para a troca com os outros. Bagagens singulares!

Ampliar a bagagem dos alunos, proporcionando "viagens artísticas" é um dos compromissos do professor. Levá-los aos espaços legitimados da arte é um desafio, tanto físico, quanto cognitivo, pois ajudá-los a perceber a relevância de uma mostra artística não é tarefa das mais fáceis, isso porque, não temos a cultura de valorizar a arte como valorizamos outras coisas, por exemplo, as áreas científicas.

O que nos ajuda é considerar que na educação as coisas são mais lentas, ou seja, temos que investir na aula e apostar no aluno, embora, às vezes, parece que fica pouca coisa, seguidamente somos tomados pela sensação de que algo nos escapa. Faltam-nos mecanismos mais objetivos para mensurar aprendizagem ${ }^{21} \mathrm{e}$, diante disso, nos resta apostar na singularidade e no tempo de cada aluno.

Potencializar a percepção e autorizar o pensamento crítico, fez com o aluno Leonel, por exemplo, se surpreendesse com o que viu nas obras de Lambrecht e Senise: "O interessante nesta obra é a dúvida que deixa sobre o que se refere à obra, o estranhamento das imagens e de suas leituras, o artista contemporâneo critica muitas coisas em suas artes". Para Leonel, a arte deixou mais perguntas do que repostas. Ele se inquieta diante da obra, e percebe que a arte apresenta questões do "ser no mundo", pois como diz Gadamer 
(apud PALMER, 1989, p.172), "[...] é a obra de arte que nos coloca uma questão, a questão que provocou o seu ser. A experiência de uma obra de arte é englobante e surge na unidade e continuidade do nosso próprio auto-conhecimento". Provavelmente, o aluno foi tocado pela especificidade da obra, por aquilo que a própria obra diz, pois como menciona Gadamer (apud LAWN, 2007, p. 41), "os trabalhos de arte nos chamam a atenção e nós temos a responsabilidade de 'ouvi-los'”. Leonel percebeu a complexidade da arte, para a qual seu olhar, talvez não seja mais ingênuo.

Através da apreciação crítica o aluno desenvolve a habilidade para ver, que é mais do que simplesmente olhar, pois será instigado a buscar informações sobre diferentes aspectos da obra.

Segundo Meira (1999, p. 136):

Não é mais possível pensar-se numa educação para a cidadania, muito menos numa educação que assuma a função de construir sujeitos, sem a garantia de uma educação estético-visual. A relação estética, as ações ético-estéticas, a contextualização e leitura estética dependem da percepção estética e da consciência imaginária sobre o sentido dessa relação. A possibilidade de pensar, agir, interagir e intervir por meio de imagens garante as condições estruturais e estruturadoras para se construir formas de aprendizagem, conhecimento, comunicação que sejam intrínsecas à via figurativa. As intervenções sociais e culturais demandam conhecimento estético que permite resolver problemáticas relativas à sensibilidade, à criatividade, mas dentro de formas de consciência e de ação, gesto, performance que possam produzir as transformações que a humanidade como um todo requer. Não basta, simplesmente, saber editar imagens ou jogar aleatoriamente com formas visuais, sem contextualizá-las num processo mais amplo de visibilidade estética, o que exige um olhar onde o emocionamento esteja sempre presente.

Meira destaca a figura do professor, enfatizando que conhecer sobre a área e saber testemunhar sobre o saber específico é pressuposto para a docência. Diante disso, fica evidente que o professor não só transpõem didaticamente o conhecimento, mas também necessita vivenciar e exercitar a arte para que as questões da especificidade da linguagem artística também se coloquem a ele. No movimento dialógico e interdisciplinar do ensino/aprendizagem, o professor anuncia questões sobre "o que ensinar", "porque ensinar" e "como ensinar". Já, “o que 
aprender", "para que aprender" e "o que fazer com esse aprendizado" deve ser discutido com o aluno para que compreenda o que está estudando e dê sentido aos saberes construídos.

Para a professora Marilda Oliveira (2006, p. 66) "um professor não é competente porque 'dá uma boa aula'. Ele é competente quando consegue articular os diferentes saberes e dar significado ao que ensina". Observa, ainda, que "o profissional precisa de tempo para trabalhar sua competência, precisa experimentar, ousar, planejar, rever, refazer [...]", ou seja, pensar e qualificar a docência.

A experiência artística que o aluno João Francisco vivenciou, por exemplo, proporcionou perceber que "[...]as pinturas eram desafiadoras e infringiam as regras, pinturas totalmente surreais que por trás delas havia algo que nos fazia pensar". Já para João Pedro, conhecer novos procedimentos e materiais serviu para entender que o artista é um ser no mundo e, está atento às coisas do seu tempo: "eu achei a forma com que os artistas transformaram lixo em arte muito interessante, assim como a forma que os artistas vêem o feio como bonito". Para ele, o entendimento dos conceitos de belo e feio se expandiram e a percepção de que o artista tem uma questão a tratar, também.

O desafio de cada aula é estabelecer relações entre as expectativas dos alunos e os propósitos do professor dando sentido à aula, evitando transformá-la num desfile de informações, como datas, nomes, estilos ou fatos pitorescos. No entanto, o modo como os tempos e os espaços escolares estão organizados, muitas vezes, não contribuem para o acontecimento de uma aula articulada, em que seja possível verificar com mais complexidade um determinado assunto. Ana Mae sugere pensar a sala de aula como um lugar de pesquisa e investigação. $\mathrm{O}$ ensino da arte deve estar em consonância com as questões atuais e a sala de aula deve ser um espelho do atelier do artista ou do laboratório do cientista, ou seja, um lugar para experimentar, verificar, analisar ${ }^{22}$.

O que Ana Mae nos faz pensar é que as aulas de arte estejam atravessadas pela experimentação, pela busca constante de informações e pesquisas, desenvolvendo novas técnicas e desafiando os educandos a descobrirem novas formas de produção da arte escolar e com isso, quem sabe também, reinventamos a própria arte/educação. Para ela,

esta maneira de propor o ensino da arte rompe barreiras de exclusão, visto que a prática educativa está embasada não no talento ou no dom, mas na capacidade de experienciar 


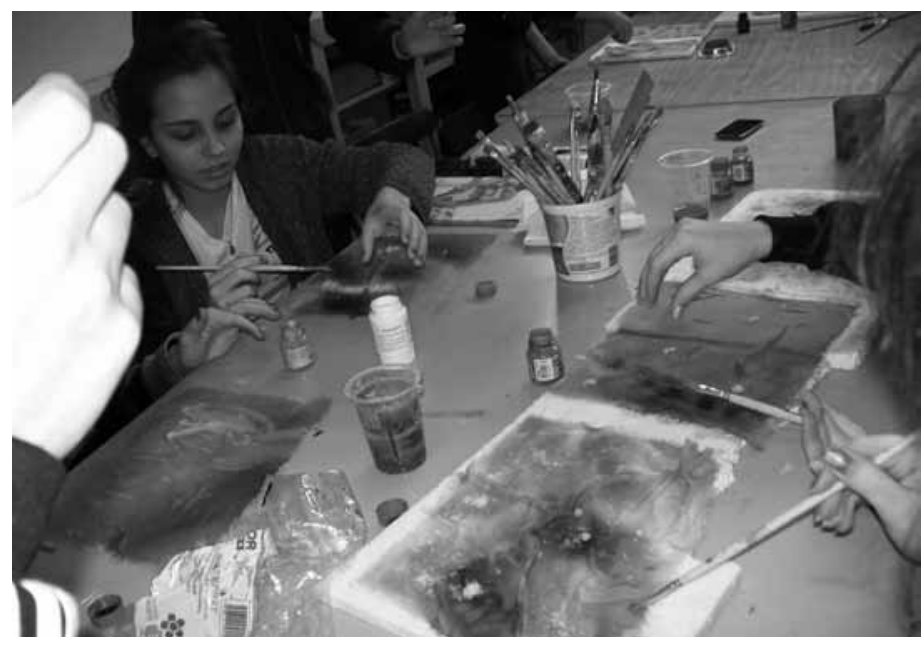

de cada um. Dessa forma, estimulam-se os educandos a se arriscarem a desenhar, representar, dançar, tocar, escrever, pois se trata de uma vivência, e não de uma competição. Uma proposta em arte que parta deste princípio traz para as suas atividades um grande número de interessados. Estas crianças e estes jovens se reconhecerão como participantes e construtores de seus próprios caminhos e saberão avaliar de que forma se dão os atalhos, as vielas, as estradas. A arte fará parte de suas vidas e terá um sentido, deixando de ser aquelas coisas incompreensíveis e elitistas, distantes de sua realidade ${ }^{23}$.

As intenções pedagógicas claras e consistentes do professor, aliadas à cumplicidade com os alunos, tendem a gerar sólidas e enriquecedoras experiências, contribuindo para a multiplicidade de trocas e qualidade das interações. Através da arte, os alunos interagem com diferentes situações, tornam-se capazes de conhecer a si mesmos, sua cultura e o mundo em que vivem, expressando-se com palavras, imagens, sons, gestos e movimentos, gerando, com isso, um sentimento de significação e pertencimento. Isso é, passam a fazer parte de um grupo que valoriza os fazeres humanos em geral e as práticas artísticas em particular, incluindo aí, as próprias produções, o desenvolvimento da curiosidade intelectual e do gosto pelo conhecimento.

\section{Para continuar pensando}

Daniel Senise e Karin Lambrecht são exemplos de artistas que criaram uma arte diferenciada e de grande valor estético. Suas
Figura 14

Imagens de alguns alunos pesquisando pintura 
obras evidenciam a maturidade de suas pesquisas assim como a ousadia e a coerência de suas propostas. Apontam questões como o que é arte, quando é arte e quem é o artista; aspectos fundamentais para a compreensão da arte contemporânea, por apresentarem elementos pertinentes para à compreensão do processo e das questões que norteiam suas pesquisas.

Essas, entre tantas outras questões, podem ser tematizadas a partir das obras de Senise e Lambrecht, porém, para isso, é preciso que o professor conheça o assunto e tenha repertório para problematizar e relacionar questões da área, ou seja, que ele tenha conhecimento e vivência o suficiente para testemunhar sobre aquilo que vai ensinar. Também se faz necessário conhecer diferentes metodologias de ensino e operar com diversos procedimentos e meios de produção artística; essas habilidades são critérios relevantes para a docência artística, embora não sejam garantias de qualidade. Meira (1999, p. 137) destaca que "o papel político do professor como mediador estético depende de sua consciência sobre as questões fundamentais que nas artes se traduzem como elementos sensíveis".

Abordar o fenômeno artístico na instituição escolar, preservando sua especificidade e garantindo uma experiência sensível, cognoscível e, também poética, é um dos objetivos da arte/educação. Dessa forma, o desafio é conduzir a aula numa relação dialógica entre professor e aluno. Criar um ambiente de investigação acerca de algo, proporcionando a problematização dos conteúdos, sendo o professor o propositor e mediador dos processos de ensino/aprendizagem e, o aluno, aquele que se lança numa busca por respostas, mesmo que provisórias e contingenciais das perguntas que faz a si, ao conhecimento e, nesse caso, ao universo da arte e da arte contemporânea.

\section{Referências}

ADES, D. Daniel Senise: vestígios. In: Daniel Senise, ela que não está. São Paulo: Cosac \& Naify, 1998.

AGUIRRE, I. Imaginando um futuro para a educação artística. In: MARTINS, R.; TOURINHO, I. (orgs.). Educação da cultura visual: narrativas de ensino e pesquisa. Santa Maria: Ed. UFSM, 2009. p. 157-186.

BARBOSA, A. M. (org.). Arte/educação contemporânea: consonâncias internacionais. São Paulo: Cortez, 2005.

BECKETT, W. História da pintura. São Paulo: Ática, 1997.

CATTANI, I. B. O corpo, a mão, o vestígio. In: Karin Lam- 
brecht, catálogo de exposições realizado no MARGS. Porto Alegre, 2002.

(Org.). Mestiçagens na arte contemporânea. Porto Alegre: Ed. da UFRGS, 2007.

CHAIA, M. Karin Lambrecht: arte, natureza e sociedade. In: Karin Lambrecht, catálogo de exposições realizado no MARGS. Porto Alegre, 2002.

DVDteca Arte na Escola. Daniel Senise: a construção da ausência. Disponível pelo Instituto Arte na Escola. Acessível no Pólo Unijuí da Rede Arte na Escola.

DVDteca Arte na Escola. Karin Lambrecht: de corpo e alma. Disponível pelo Instituto Arte na Escola. Acessível no Pólo Unijuí da Rede Arte na Escola.

FARIAS, A. Daniel Senise. In: Daniel Senise: livro de artista. São Paulo: Códex, 2002.

FARIAS, A. In: Karin Lambrecht, catálogo de exposições realizado no MARGS. Porto Alegre, 2002.

GIL, V. As vestes na série registros de sangue, de Karin Lambrecht. In: CATTANI, I. (org.). Mestiçagens na arte contemporânea. Porto Alegre: Ed. UFRGS, 2007. p. 183-192.

LAWN, C. Compreender Gadamer. Petrópolis, RJ: Vozes, 2007.

MARTINS, M. C. Bagagens, alfândegas e passageiros. In: CORREA, A. D. (org.). Ensino de artes: múltiplos olhares. Ijuí: Ed. Unijuí, 2004. p. 237-246.

MEIRA, M. R. Educação estética, arte e cultura do cotidiano. In: PILLAR, A. D. (org.). A educação do olhar no ensino das artes. Porto Alegre: Mediação, 1999.

MESQUITA, I. Território dos sentidos. In: Daniel Senise, ela que não está. São Paulo: Cosac \& Naify, 1998.

OLIVEIRA, M. O. O.; HERNÁNDEZ, F. (orgs.). A formação do professor e o ensino das artes visuais. Santa Maria, RS: Ed. UFSM, 2005.

OMAR, A. Daniel Senise. In: Daniel Senise: livro de artista. São Paulo: Códex, 2002.

PALMER, R. E. Hermenêutica. Lisboa, Portugal: Edições 70 LTD, 1989.

PCN - PARÂMETROS CURRICULARES NACIONAIS. Arte/ secretaria de educação fundamental. 2. ed. Rio de Janeiro: DP\&A, 200o. v. 6.

SANTOS, S. M. P. O lúdico na formação do educador. Petrópolis, RJ: Vozes, 1997.

SEVERO, A.; BERNARDES, M. H. (orgs.). Eu e você. Santa Cruz do Sul: EDUNISC, 2001. 
THISTLEWOOD, D. Arte contemporânea na educação, des-construção, re-construção, reações dos estudantes britânicos e brasileiros ao contemporâneo. In: BARBOSA, A. M. (org.). Arte/educação contemporânea: consonâncias internacionais. São Paulo: Cortez, 2005. p. 113-125.

1. Daniel Senise "nasceu em 1955 no Rio de Janeiro. Em 1980, se formou em engenharia civil pela Universidade Federal do Rio de Janeiro, tendo ingressado na Escola de Artes Visuais do Parque Lage no ano seguinte, onde participou de cursos livres até 1983. Foi professor na mesma escola de $1985 \mathrm{a}$ 1996. [...] Tem exposto individualmente em museus e galerias no Brasil e no exterior. Atualmente, o artista vive e trabalha no Rio de Janeiro. Fonte http:// www.danielsenise.com/daniel-senise/biografia/ - acesso em julho de 2011.

2. Karin Marilin Haessler Lambrecht (Porto Alegre RS 1957). Pintora, desenhista, gravadora e escultora. [...] Em sua produção dos anos 1980, emprega detritos industriais, dialogando com a arte povera e o expressionismo. Nesse período, dedica-se ainda à pintura, em busca de novas possibilidades formais, elimina chassis e costura pedaços de tela. Na década de 1990, começa a agregar materiais orgânicos, como grãos de terra e sangue, à superfície das telas. Fonte: http://www.itaucultural.org.br/aplicexternas/enciclopedia_ic/index.cfm?fuseaction=artistas_biografia\&cd verbete $=\mathbf{2 3 9 0} \& \mathrm{~cd} \_$item $=\mathbf{2} \& \mathrm{~cd} \_$idioma $=\mathbf{2 8 5 5 5}$ - acesso em julho de $\mathbf{2 0 1 1}$.

3. O aspecto artístico diz respeito ao modo como a obra foi realizada: materiais, procedimentos, meios. Já o aspecto estético diz respeito à composição/articulação da obra, sua plasticidade, fundamento filosófico e ao padrão de beleza.

4. DVDs do Arte na Escola, "Karin Lambrecht: de corpo e alma", e "Daniel Senise: A construção da ausência" doado pelo Instituo Arte na Escola e disponível no acervo do Pólo Unijuí da Rede Arte na Escola - Unijuí.

5. (http://www.google.com.br/search?hl=pt-BR\&source=hp\&q=ana+mae+ barbosa\&aq=o\&aqi=g8g-s1g1\&aql=\&oq=ana+mae\&gs_rfai=em 24/o4/10).

6. Destaca-se que "os paradigmas modernos foram reforçados e, paradoxalmente questionados pelas segundas vanguardas dos anos 1960 e 1970. As práticas artísticas que começam ao mesmo tempo que aquelas nos anos 1970 e, sobretudo, a partir dos anos 1980, apresentam novas problemáticas que permitem considerações sobre a possibilidade da existência de uma produção artística pós-moderna" (CATTANI, 2007, p. 24). No caso de Senise e Lambrecht, a questão está centrada no conceito de pintura que reinventam, contrapondo-se com a arte moderna brasileira em que a pintura estava centrada na figuração e nas abstrações, enfatizando materiais como acrílica, óleo e colagens. Num contexto de abertura política, os artistas em questão se voltam para a experiência artística, para uma dimensão mais introspectiva da criação, em que as questões históricas (políticas, sociais) se apresentam transversalmente e/ou sutilmente.

7. Marcel Duchamp, artista dadaísta que incorporou objetos de cotidiano em suas obras e também criou categorias como Ready-made e Objet-trouvé. É de 1917 a obra Fontain que ficou referenciada como um marco simbólico entre arte moderna e arte contemporânea.

8. Frottage: No frottage o artista utiliza um lápis ou outra ferramenta de desenho e faz uma "fricção" sobre uma superfície texturizada. O desenho pode ser deixado como está, ou pode ser utilizado como base para aperfeiçoamento. 
9. Texto publicado no catálogo da exposição do artista no Museu Oscar Niemeyer, Curitiba, em 2006. Entrevista de Daniel Senise a Agnaldo Farias. (Retirado do site seeartadvisory.com em 08/02/11).

10. Maruflagem: Processo da pintura que recebe esse nome por causa da cola que utiliza, chamada "marufle", muito forte e resistente, normalmente usada por pintores para reforçar uma tela com outra ou para aplicar um suporte sobre outro, como, por exemplo, colar uma tela sobre parede ou madeira ou uma pintura feita sobre papel numa tela.

11. Fonte da imagem: http://www.google.com.br/imgres?imgurl=http:// www.nossadica.com/fto_exposicao/Daniel\%2520Senise.

jpg\&imgrefurl=http://www.nossadica.com/casa-franca-brasil.php\&usg= oNtsAZUeTRl8Zd 7 dWNFjPXewxS $4=\& \mathrm{~h}=332 \& \mathrm{w}=500 \& \mathrm{sz}=41 \& \mathrm{hl}=\mathrm{pt}-$

-BR\&start $=8 \&$ zoom $=1 \&$ tbnid $=$ DIy1QD -1 nUhDM:\&tbnh $=86 \&$ tbnw $=130 \& \mathrm{e}$ $\mathrm{i}=8$ ShETr6kEOLaoQHRiazYCQ\&prev=/search $\% 3 \mathrm{Fq} \% 3 \mathrm{Dfotos} \% 2 \mathrm{Bdo} \% 2 \mathrm{Ba}$ rtista\%2Bdaniel\%2Bsenise\%2Bpintando\%2Bno\%2Batelier\%26um\%3D1\% 26hl\%3Dpt-BR\%26sa\%3DN\%26biw\%3D1003\%26bih\%3D 529\%26rlz\%3D 1W1ADSA_pt-BR\%26tbm\%3Disch\&um=1\&itbs=1 - acesso em julho de 2011.

12. Depoimento retirado do documentário "Karin Lambrecht: de corpo e alma” Disponível na DVDTEca do Pólo Unijuí da Rede Arte na Escola Instituto Arte na Escola.

13. Depoimento de Karin Lambrecht em entrevista a Camila Gonzatto para a Revista Digital do site da Fundação Iberê Camargo - 2009. Acesso em 28/08/10.

14. Viviane Gil (2007, p. 183) cita Cattani (2004) para mencionar que esses suportes não são neutros, mas investidos de lembranças da sua história pessoal, como as toalhas que pertencem à sua avó materna, vinda da Rússia e, que se oferecem como uma nova base para a pintura. Elas estão gastas, remendadas, tendo servido durante três gerações para decorar numerosas reuniões e festas familiares.

15. Trechos extraídos do DVD "Karin Lambrecht: de corpo e alma”, doado pelo Instituo Arte na Escola e disponível no acervo do Pólo Unijuí da Rede Arte na Escola - Unijuí.

16. É necessário observar que na hora de realizar a pintura com sangue o mesmo já estava coagulado, dificultando um pouco o manuseio que precisou ser feito com a ajuda de um pincel. Também teve o problema do cheiro, pouco tempo depois estava muito forte e ninguém queria ficar perto. Os trabalhos foram jogados fora e não foi possível registrar com fotografias. Após analisarem como era o resultado do sangue sobre o tecido, fazendo comparações entre o trabalho deles e o de Karin, disseram que o dela estava com mais "vida", talvez pela quantidade e vitalidade do sangue utilizado.

17. Maria Regina Johann usa o termo arte escolar para designar as realizações artísticas escolares, porque se valem da arte tomando emprestadas suas ideias, mas não tem a pretensão de ser arte, uma vez que os estudantes não possuem as mesmas intencionalidades do artista ao realizarem suas produções.

18. (Entrevista concedida por Ana Mae Barbosa a Agência USP de Notícias.) FONTE: http://www.usp.br/agen/bols/200o/rede529.htm ensinandoartesvisuais.blogspot.com em 17-09-10.

19. Jorge Larrosa é professor da Universidade de Barcelona e doutor em Filosofia da Educação. Ver texto "Notas sobre a experiência e o saber de experiência” disponível em http://www.anped.org.br/rbe/rbedigital.

20. Não identificamos o autor da obra, assim como, seu título. 
21. Aspectos próprios da dimensão humana.

22. Trechos extraídos de entrevista pessoal com Ana Mae Barbosa e entrevistas concedidas a Agência Repórter Social (jornalista Flávio Amaral) e Museu de Arte Contemporânea da USP.

23. (http://caracol.imaginario.com/paragrafo_aberto/rml_arteduca.html em 24/04/10).

Recebido em: 07/10/11

Aceito em: 07/02/12 


\section{MARIA REGINA JOHANN}

maria.johann@unijui.edu.br

Professora dos cursos de Artes Visuais Licenciatura e Bacharelado, Design e Pedagogia da Unijuí. Graduada em Educação Artística - Habilitação Artes Plásticas e Mestre em Educação nas Ciências pela Unijuí. Coordenadora pedagógica do Pólo Unijuí da Rede Arte na Escola e Integrante do Grupo de artistas Artes Seis (Ijuí).

\section{GICELDA DE LUCCA FLORES}

gicelda_lucca@hotmail.com

Acadêmica do Curso de Licenciatura em Artes Visuais da Unijuí e

professora de pintura em atelier. Reside em Palmeira das Missões, RS. 